\title{
The Transfer of Knowledge in Intra-Organizational Networks: A Case Study Analysis
}

\author{
Włodzimierz Sroka', Joanna Cygler², Bożena Gajdzik ${ }^{3}$
}

\author{
${ }^{1}$ Department of Management, Academy of Business in Dąbrowa Górnicza, Cieplaka Street 1c, 41-300 Dąbrowa \\ Górnicza, Poland, wsroka@wsb.edu.pl (corresponding author) \\ ${ }^{2}$ Warsaw School of Economics, Institute of Management, Niepodległości ave. 162, 02-554 Warszawa, \\ Poland, cygler@sgh.waw.pl \\ ${ }^{3}$ Department of Materials Science \& Metallurgy, The Silesian University of Technology in Gliwice Akademicka \\ street 2A, 44-100 Gliwice, Poland, bozena.gajdzik@polsl.pl
}

Background: In today's business environment, a company is able to maintain its competitive position if it constantly generates knowledge and disseminates this knowledge within the organization, as well as transforms it into new competences. The ability to transfer knowledge becomes one of the key factors in the improvement of a company's competitive position. This hypothesis is applicable particularly in the case of cooperation within networks, as they are an excellent opportunity for mutual learning between partners.

Objectives: The purpose of the paper is to analyse the process of knowledge transfer in intra-organizational networks. Method: Due to the specificity of the research object, the case study method has been chosen. In order to make an in-depth analysis of the case study, we selected a group of several criteria based on the theory which we believe to be fundamental to the effectiveness of knowledge management in networks, and compared them with the situation in the ArcelorMittal Group.

Results: Our research show that ArcelorMittal Group has met almost all the criteria of effective knowledge management in its intra-organizational network. Some exceptions, albeit merely to an extent, are mostly the result of historical circumstances, , i.e. the process of growth through acquisitions, and the acquisition of companies at different stages of organizational development, as well as organizational culture.

Conclusion: Based on theoretical assumptions, the study analysed in details the components of knowledge management applied by the corporation in question. Therefore this study might be utilised to formulate a refutable hypothesis and verify them on a larger group of companies from different sectors of the economy. The main limitations of the paper are mostly related to the inherent approach therein.

Keywords: knowledge, knowledge transfer, knowledge management, network, case study analysis

\section{Introduction}

In recent years, many strategic management scholars have paid close attention to knowledge management, both at the organizational level (e.g. Spender and Grant, 1996; Argote et al., 2003) as well as in terms of inter-organizational cooperation (Powell, 1998; Ingram and Simons, 2002; Lake and
Erwee, 2005; Eunni et al., 2006). The concept of knowledge management goes beyond the single-discipline, covering the areas of strategic management, economics, information systems, psychology and sociology. This diversity has contributed to the rapid progress of knowledge in various areas of organizational learning and knowledge management. Knowledge-oriented concepts which had previously

Received: $21^{\text {st }}$ July 2013; revised: $9^{\text {th }}$ September 2013; accepted: $29^{\text {th }}$ October 2013 
been little known, such as "organizational competence", "organizational learning", "intangible assets", "organizational capacity", or "tacit knowledge", have become widely used; and key competencies of organizations are thus based on the finding and creation of knowledge.

It is claimed that companies which do not actively manage knowledge as a key resource will not be able to sustain growth and competitiveness (Conradie, 2010). In today's business environment, a company is able to maintain its competitive position if it constantly generates knowledge and disseminates this knowledge within the organization, as well as transforms it into new competences (Nonaka, 1991). The ability to transfer knowledge becomes one of the key factors in the improvement of a company's competitive position. This hypothesis is applicable particularly in the case of cooperation within networks, as they are an excellent opportunity for mutual learning between partners. For example, Goerzen (2007) claims that through participation in networks, companies obtain swift access to knowledge and information which would otherwise be inaccessible.

The paper is structured as follows: first, we review the literature on knowledge and knowledge management in intra-organizational networks. The main sources of theoretical analysis are scientific journals, specifically those publications devoted to knowledge management in alliance networks. Based on this review, we then present guidelines for knowledge transfer within such networks. The following section concentrates on a case study analysis based on the ArcelorMittal Group, which has successfully implemented the Knowledge Management Program. Finally, we discuss the results of our study and draw some conclusions as well as presenting the limitations of our research.

\section{Literature review}

Knowledge has emerged as the most strategically significant resource of today's business enterprise (Grant, 1996) and a core component of a company's strategic intent. If an enterprise wants to improve its competitiveness, it has to acquire new competences obtained through cooperation with other entities, as cooperative relationships with competitors constitute a potential alternative to the generation of internal knowledge (Richter and Vettel, 1995). Networks between companies are an effective way to create competitive advantage through a combination of the complementary resources of network members (Gilsing and Lemmens, 2007). The structure of the network affects the process of knowledge transfer within the network, and companies occupying a central position in an intra-organizational network are characterized by greater innovation, as a result of better and wider access to knowledge (Tsai, 2001).

The frequency of contacts between the parties positively affects the quality and speed of knowledge transfer (Uzzi, 1991), and stronger relationships within an intra-organiza- tional network favour the transfer of complex knowledge, while weaker ties prefer the transfer of simple knowledge (Hansen, 1999). In turn, if there are structural holes amongst network members, its innovativeness will be lesser (Ahuja, 2000). Moreover, the more organizational units which are of key importance to the network, the quicker the transfer of knowledge (Tang, 2011).

The process of knowledge transfer is based on the concept of the learning organization which facilitates the acquisition of experience and learning (Hamel, 1991). Companies which want to enhance competitiveness through knowledge management can only achieve this if there is a culture of learning. There is an inter-relationship between knowledge and organizational learning, and learning plays an important role in ensuring that knowledge is created and transferred to promote innovation. The shared values of innovation and learning need to be managed and utilized successfully to sustain economic growth and competitive advantage (Kok, 2004). In addition, this knowledge would be better transferred, absorbed and utilized if the members of the network were more closely related (both vertically and horizontally). This is directly related to the increase in mutual trust and reduction of opportunistic behaviour (Blois, 1990).

A key success factor in the transfer of knowledge within networks is absorption. When acquiring new knowledge, organizational units use their existing skills and knowledge (Zahra, 2002). The level of knowledge absorption in the network is also the result of absorption of individuals involved in the creation of this unit. Therefore the formation of creative and professional teams is a necessary condition for the maintenance of a sufficiently high level of absorption. There are two factors affecting a company's absorptive capacity. One relates to the internal factors, such as organizational structure, size, strategy, prior knowledge base, and organizational responsiveness; the other one is external factors, which include external knowledge environment and a firm's position in knowledge networks (Lee \& Chi Wu, 2010).

Equally important to the quality of knowledge transfer is the sender's ability to spread. These issues have received much less attention from researchers, despite the importance of the knowledge sender's disseminative capacity to the success of the transfer. Parent et al. (2007) explain this capacity as "the ability to contextualize, format, adapt, translate and diffuse knowledge through a social and/or technological network and to build commitment forms of stakeholders". Disseminative capacity is related to the likelihood of precise, clear and effective articulation and transfer of knowledge to other members of the network. These capabilities include the transfer of knowledge in conceptual form, and the familiarization of customers with its practical implementation.

It is increasingly stressed that the transformation of knowledge possessed by the sender into value which has value for customers, is needed (Kulken and van der Sijde, 2010). Therefore, the sender should have creativity, knowl- 
edge, communication skills and the appropriate personality traits. The knowledge transfer is faster if the sender's ability to disseminate knowledge is greater. This, however, depends on the degree of homogenization of the network and the strategy of its members, as well as on the uniformity and strength of organizational culture (Abrahamson and Fombrum, 1994). However, disseminative capacity depends not only on the skill of the sender, but also on its willingness to transfer knowledge. Research undertaken by Minbaeva and Michailova (2004) show that the disseminative capacity of knowledge senders is greatly increased when there exist both the ability and willingness to transfer knowledge, both of which are crucial to the quality of this process.

Another factor influencing the quality of knowledge transfer is its inherent nature. Organizational knowledge can be divided into explicit knowledge, which is to say knowledge which can be codified; and tacit knowledge which is hidden and difficult to indicate (Polanyi, 1966). No difficulties are usually encountered in the transfer of codified knowledge, but its value to the organization is lower than for tacit knowledge. Although hidden knowledge is extremely beneficial for the company, it is also very difficult to transfer it to partners within a network. The main reason is the fact that understanding and explaining this knowledge requires a significant period of time, and therefore slows down the development of new products or production competences. Johannessen and Olsen (2003) also claim that tacit knowledge can be a barrier to innovation because it is usually part of a long-term learning process in a specific environment. On the other hand, Barney (1991) claims that tacit knowledge is regarded as a basis for the creation of competitive advantage.

In addition, Szulanski (1996) pointed out the danger of multiplicity and ambiguity in the interpretation of transferred knowledge and its relative novelty. Knowledge, especially informal, can be interpreted differently by the recipients according to their perception and prior experience. The problem arises when there is a network in which knowledge transfer is multilateral, and both direct and indirect. In turn, knowledge which has no documentary history causes substantial complications in the transmission and reception thereof, in terms of an intra-organizational network. It requires the parties to develop their own procedures for the reporting, acquisition and exploitation of the new knowledge. One then expects greater flexibility, openness, innovation and the commitment of all network members and their appropriate capacity, depending on their functions both within the network and in the process of knowledge transfer.

The transfer of knowledge in an intra-organizational network requires certain procedures and rules. It has been claimed that each network would be better advised to develop its own programs, depending on different factors such as: strategy, the network structure and specificity of network members, type of knowledge being transferred, etc. The program of knowledge transfer in an intra-network defines the rules regarding the selection of knowledge to be transferred to the different groups of customers at the proper time (Hutzschenreuter and Horstkotte, 2010). The transfer of knowledge is much more efficient when the parties involved in the cooperation processes are similarly trained and educated (Reagan \& McEvily, 2003).

It is worth noting that the central unit is the initiator of the creation of knowledge transfer in an intra-organizational network. However, bottom-up initiatives are also valuable. A knowledge transfer program is characterised by substantial flexibility, and varies depending on the nature and needs of the network members; the strategic goals of the organization; as well as its organizational and financial resources. It requires a certain level of specialization from the members of the network. The specialization of companies in the network is associated with the division of labour and tasks between them, which may be more or less intense. Both cases are related to the need for the exchange of knowledge in terms of products and processes, as well as proper coordination thereof (Kotabe et al. 2003). Research confirms the usefulness of both formal and informal relationships between member companies in terms of access to knowledge and its transfer between partners. Such companies benefit from cooperation in that they are then able to improve their core competencies (Lorenzoni and Lipparini, 1999).

We have presented only selected information and data regarding knowledge and knowledge management which can be found in the literature. The chosen works exhibit some common features in that all the authors underline the importance of knowledge, both at the organizational level as well as at the network level. Therefore, knowledge requires proper management; and the process of the transfer of knowledge is especially important in networks due to the following factors: (a) the different members of the network and their specificity, (b) the network structure, (c) the type of knowledge transferred, (d) expertise, and (e) distribution channels. All these elements create a system of knowledge transfer within the network. The quality of this system will depend both on its individual components as well as the system as a whole. On the other hand, a properly designed knowledge transfer system is a prerequisite for the effective transfer of knowledge in the network which can in turn generate a competitive advantage. Table 1 presents a summary of the most important approaches and concepts related to the knowledge transfer in the networks.

\section{Case Study Analysis}

\subsection{Choice of methodology}

Welch et al. (2011) claim that the case study has an established place in qualitative international business research. This is not surprising, given its potential to generate novel and ground breaking theoretical insights. Case studies pro- 
Table 1: The most important approaches and concepts related to the knowledge transfer in the networks.

\begin{tabular}{|c|c|c|}
\hline No. & Author & Description of the approach \\
\hline 1. & $\begin{array}{l}\text { Gilsing and } \\
\text { Lemmens, } 2007\end{array}$ & $\begin{array}{l}\text { Networks between companies are an effective way to create competitive advantage } \\
\text { through a combination of the complementary resources of network members. }\end{array}$ \\
\hline 2. & Tsai, 2001 & $\begin{array}{l}\text { The structure of the network affects the process of knowledge transfer within the network; } \\
\text { companies occupying a central position in an intra-organizational network are character- } \\
\text { ized by greater innovation, as a result of better and wider access to knowledge. }\end{array}$ \\
\hline 3. & Uzzi, 1996 & $\begin{array}{l}\text { The frequency of contacts between the parties positively affects the quality and speed of } \\
\text { knowledge transfer. }\end{array}$ \\
\hline 4. & Hansen, 1999 & $\begin{array}{l}\text { The stronger relationships within an intra-organizational network favour the transfer of } \\
\text { complex knowledge, while weaker ties prefer the transfer of simple knowledge. }\end{array}$ \\
\hline 5. & Ahuja, 2000 & If there are structural holes amongst network members, its innovativeness will be lesser. \\
\hline 6. & Tang, 2011 & $\begin{array}{l}\text { The more organizational units which are of key importance to the network, the quicker the } \\
\text { transfer of knowledge. }\end{array}$ \\
\hline 7. & Hamel, 1991 & $\begin{array}{l}\text { The process of knowledge transfer is based on the concept of the learning organization } \\
\text { which facilitates the acquisition of experience and learning. }\end{array}$ \\
\hline 8. & Zahra, 2002 & $\begin{array}{l}\text { A key success factor in the transfer of knowledge within networks is absorption. When } \\
\text { acquiring new knowledge, organizational units use their existing skills and knowledge. }\end{array}$ \\
\hline 9. & $\begin{array}{l}\text { Kulken and van der } \\
\text { Sijde, } 2010\end{array}$ & $\begin{array}{l}\text { The transformation of knowledge possessed by the sender into value which has value for } \\
\text { customers, is needed. Therefore, the sender should have creativity, knowledge, communi- } \\
\text { cation skills and the appropriate personality traits. }\end{array}$ \\
\hline 10. & $\begin{array}{l}\text { Abrahamson and } \\
\text { Fombrum, } 1994\end{array}$ & $\begin{array}{l}\text { The knowledge transfer is faster if the sender's ability to disseminate knowledge is great- } \\
\text { er. This depends on the degree of homogenization of the network and the strategy of its } \\
\text { members, as well as on the uniformity and strength of organizational culture. }\end{array}$ \\
\hline 11. & Polanyi, 1966 & $\begin{array}{l}\text { An important factor influencing the quality of knowledge transfer is its inherent nature. } \\
\text { No difficulties are usually encountered in the transfer of explicit (i.e. codified) knowl- } \\
\text { edge. In turn, tacit (hidden) knowledge is very difficult to transfer to partners within a } \\
\text { network. The main reason is the fact that understanding and explaining this knowledge } \\
\text { requires a significant period of time, and therefore slows down the development of new } \\
\text { products or production competences. }\end{array}$ \\
\hline 12. & $\begin{array}{l}\text { Johannessen and } \\
\text { Olsen } 2003\end{array}$ & $\begin{array}{l}\text { Tacit knowledge can be a barrier to innovation because it is usually part of a long-term } \\
\text { learning process in a specific environment. }\end{array}$ \\
\hline 13. & Barney (1991 & Tacit knowledge is regarded as a basis for the creation of competitive advantage. \\
\hline 14. & Szulanski, 1996 & $\begin{array}{l}\text { The danger of multiplicity and ambiguity in the interpretation of transferred knowledge } \\
\text { and its relative novelty. }\end{array}$ \\
\hline 15. & $\begin{array}{l}\text { Hutzschenreuter and } \\
\text { Horstkotte, } 2010\end{array}$ & $\begin{array}{l}\text { The transfer of knowledge in an intra-organizational network requires certain procedures } \\
\text { and rules. It defines the rules regarding the selection of knowledge to be transferred to the } \\
\text { different groups of customers at the proper time. }\end{array}$ \\
\hline 16. & $\begin{array}{l}\text { Reagan and } \\
\text { McEvily, } 2003\end{array}$ & $\begin{array}{l}\text { The transfer of knowledge is much more efficient when the parties involved in the coop- } \\
\text { eration processes are similarly trained and educated. }\end{array}$ \\
\hline
\end{tabular}

Source: own elaboration 
vide the research framework within which an observation and analysis of behaviour in relation to both structure and mechanisms can be conducted (Klonoski, 2013). They are generally constructed to explain the mechanism contributing to a described event and to interpret its social, cultural and organizational meanings rather than to create predictions about future events (Wynn and Williams, 2012). Given these considerations, the case study method has been chosen due to two main reasons. The first was the specificity of the research object. Another reason was in-depth local knowledge of the authors of the object analysed. As Fenno (1986) claims, if the researchers have this local knowledge they are in a position to "soak and poke", and thus to offer reasoned lines of explanation based on this rich knowledge of setting and circumstances. This knowledge is the result of the author's work in the object in question. Case studies are analyses of persons, events, decisions, periods, projects, policies, institutions, or other systems that are studied holistically by one or more methods (Thomas, 2011). Yin (1981) indicates that the case study method can be employed if "it attempts to examine: (a) a contemporary phenomenon in its real-life context, especially when (b) the boundaries between phenomenon and context are not clearly evident". Our research object fulfils both conditions.

Case study research can be used to generate and test theories within a positivist paradigm (Eisenhardt, 1989). Furthermore, a recent review of articles published in four core international business journals over a 10 -year period found case studies to be the most popular qualitative research strategy (Piekkari et al. 2009). An analysis of the complexity of the network (including the transfer of knowledge) requires a comprehensive approach, which is supported by case study research. The case presented in this paper is more descriptive than explanatory or exploratory (Yin, 1994), in which the key issue is to describe the phenomenon, together with the circumstances of its occurrence (Mitchell, 1980). This, however is also an another advantage of the case study presented, as the readers will have an opportunity to learn about the problems with knowledge management which they may encounter. Therefore it may be also useful for the companies operating in a variety of industries.

On the other hand it should be noted that there are indeed both advantages and disadvantages of this research method. The advantages of the case study method include its applicability in such cases when the research object is difficult to examine through quantitative methods, or when it is relatively new (in other words when a lack of previous studies exist in the literature). This method is also flexible and creative (Patton, 2002; Marelli, 2007). In turn, the weakness of this method includes the emotional attitudes of researchers to the object of the study, which may affect the objectivity of the conclusions (Smith, 1990) and the requirement for a high level of analytical abilities and writing skills. Welch et al. (2011) also observe that literature on case studies has tended to focus on the methods of data collection and analy- sis rather than the methods of theorizing from case studies. Therefore, as has been stated by Tsang (2012), the theorizing potential of case studies has not been fully realized in the field of international business research.

\subsection{Description of ArcelorMittal Group}

The case study analysis concentrates on the steel industry, and more specifically on ArcelorMittal, the world leader in this industry. The research object was selected because of the following reasons:

- ArcelorMittal is a wide capital group which crates the network in international scale. This geographical dispersions requires a constant shaping the effective transfer of knowledge within the network;

- previous research confirmed the existence of network connections in Polish steel industry (e.g. Lisiński et al. 2012; Sroka 2012) and ArcelorMittal controls approx. 70 percent of Polish steel sector capacity. It can then be assumed that the network connections can be applied to the whole corporation;

- in the frame of its intra-organizational network, the group has developed the original solutions related to processes as well as structures of knowledge transfer (e.g. Sroka, 2010 b). This is unquestionable and influences the market, organizational, as well as financial results of the whole group;

- successes and failures in the process of knowledge transfer are not a specific feature of this corporation only. They have a universal nature and can be applied by other corporations with a similar geographical scope and/or branch relationship. Growing globalization causes that the experiences of some corporations can be analyzed and utilized by the others.

The steel sector is highly differentiated in terms of strategic orientation. The following normative categorisation can be used as an overall framework for describing the industry (Boston Consulting Group, 2007):

- global players,

- regional champions,

- niche specialists.

Arcelor-Mittal (which was set up in 2006 as a result of about 50 smaller transnational mergers, where Arcelor originated from Arbed in Luxembourg, Usinor in France and Aceralia in Spain) is a true global player in the steel industry. It has a world-wide network with production facilities in each region and a full range of products, producing more than 50 million tonnes, and has backward integration. It is a worldwide leader in the steel industry, a fact which increases its bargaining power with suppliers and consumers alike. No consolidation transaction in the steel industry prior to this merger was of either comparable scale or scope (Sroka, 2010a). External growth is treated as the main stra- 
tegic direction of the group, which is treated as the only "truly global" steel company. ArcelorMittal is the leader in all markets which it serves, i.e. the automotive industry, primary transformation, construction, household appliances, metal processing, general industry, packages etc. The revenues of ArcelorMittal reached \$105 billion in 2007 and market share increased to almost 10 percent (Granboualan et al. 2008). One year later revenues reached $\$ 124,9$ billion and total production rose to 103 million tons of steel. The group also occupies a world-leading position in the field of research and development (Wiechoczek, 2009).

A characteristic feature of the ArcelorMittal Group is the network connections between its particular companies. Additionally, the ArcelorMittal Group includes a number of companies situated in former Soviet Union bloc countries (Poland, Romania, the Czech Republic, Ukraine, and Kazakhstan), so the organizing of production activities is broadly similar in each steelworks. Relations between organizational units are horizontal in nature, and hierarchical in terms of relations with headquarters. Intra-organizational coopetition relations include both branch level, and corporate level. Those units cooperate with each other, while at the same time facing internal competition. Therefore, it can be said that ArcelorMittal Group is a prototypical example of an intra-organizational network, with a number of steel divisions located throughout the world. In other words, it represents all the features of such a network.

\subsection{Knowledge Management Program}

We analysed the assumptions of knowledge management programs within the ArcelorMittal Group, which had previously implemented the assumptions of knowledge transfers internally (ArcelorMittal Knowledge Management Program - KMP). A key component of the program is the participation of managerial staff in the "Manager Academy". The Manager Academy Program was implemented in 2006 and comprises three main blocks (Gajdzik, 2008):

- Fundamentals and knowledge - its purpose is to construct new employee approaches and new organizational culture and goodwill,

- Management skills - covering performance management, leadership, personal effectiveness, and team leadership; generally speaking its purpose is to improve the skills and competences of the management staff,

- Professional skills - consisting of training in innovative and analytical thinking, dealing with stress, decision making, labour law, recruitment interviews, lean manufacturing, value chain management, project management, commercial negotiations and negotiation techniques, business communication, change management, and conflict resolution.

The Program has a long-term perspective and, within ArcelorMittal Poland only, three subsequent editions were undertaken, each for around 300 people. The Program was broken down into four levels: level 1 - top management; level 2- senior management; level 3 - middle-level management; and level 4 - junior management.

This project is part of the Global Development Executive Program. It is assumed that executives will gain new analytical, interpersonal, managerial, as well as leadership skills, which should inspire them to make changes at different levels of the corporate hierarchy. Lower-level employees can use the knowledge available through the system of human resource development (International Corporate Training and Development Program) via the Intranet and the Internet.

ArcelorMittal implemented an e-learning program in which employees have access to, inter alia, the Global English Service (http://www.globalenglish.com), enabling them to learn English; Online Training Center (OTC) Thomson NETg (http://www.netglearning.com) which functions as the training centre for the following departments: accounting and finance, customer service, human resource management, sales, marketing, project management; Business Book Review - literature which is thematically linked to the production processes; and Steel University, an English-language dictionary containing vocabulary specific to the steel industry.

Another important component of the program is the exchange of knowledge and experience amongst the employees of the corporation as a whole. It is worth adding that such an exchange of knowledge relates to both the senior management level and individual employees, as part of the 'crossing' process. Crossing means that employees in identical positions perform the same tasks in other divisions of the corporation.

The group organizes internal meetings, treating them as part of the exchange of experience; holds meeting with experts and scholars outside its structures; as well as participating in national and international conferences, symposia and workshops. Generally, the group systematically organizes training sessions in order to cover all potentially problematic areas (customer service, industrial safety, SAP rules, legal regulations, etc.). It is estimated that approximately 35 percent of its staff are trained every year, and furthermore that knowledge is distributed via an effective system of communication.

Based on the analysis of ArcelorMittal's activities devoted to knowledge management, it is clear that the sharing of knowledge and the implementation of best practices are integral to its management philosophy. Through its global Knowledge Management Program, ArcelorMittal shares, develops and utilizes its knowledge and experience across all the existing facilities and subsidiaries to accelerate improvement in business performance. The KMP comprises all key functional areas, such as procurement, marketing, logistics, health and safety, steel production and processing, and customer service. The KMP includes ongoing benchmarking, regular technical meetings and information- 
sharing at the corporate, regional and operational levels to drive improvement in performance, enabling each business unit to benefit from economies of scale and access to the best practices and experience available within the corporation. Therefore, the KMP contributes to enhanced quality, productivity and profitability across the whole group.

\section{Theoretical assumptions vs. case study analysis - comparison}

In order to make an in-depth analysis of the case study, we selected a group of several factors (criteria) based on the theory which we believe to be fundamental to the effectiveness of knowledge management in networks, and compared them with the existing situation in the ArcelorMittal Group. The results are presented in Table 2.

An analysis of Table 2 shows that ArcelorMittal Group has met all the criteria of effective knowledge management in its intra-organizational network. Some exceptions, albeit merely to an extent, are mostly the result of historical circumstances, i.e. the process of growth through acquisitions, and the acquisition of companies at different stages of organizational development, as well as organizational culture. This can limit the ability to absorb knowledge; however not excluding it completely, of course. Another issue relates to coopetition, which is mostly a feature of interorganizational networks. The nature of the ArcelorMittal network, which can be classified as intra-organizational, means that aspects of cooperation dominate the competition; yet some limited level of competition exists, and has a positive effect.

One of the key elements of modern management is knowledge management, a thesis which is borne out by the results of ArcelorMittal operations. It posted a net profit of $\$ 2.26$ billion in 2011. In turn, 2012 was a very difficult year for the steel industry, particularly in Europe, where the demand for steel fell a further 8.8 percent, and the slowdown in China's economy. As a result, ArcelorMittal posted a net loss of $\$ 3.73$ billion. The company's sales were also down 10.39 percent to $\$ 84.21$ billion in 2012. To give but one example, due to overcapacity and reduced demand in Europe, ArcelorMittel had 9 of 25 blast furnaces sitting idle, and in October 2012 it permanently shut down two blast furnaces at its steel plant in Florange (France). However, one expects an improvement in the situation in 2014. The worsening in results from last year cannot, however, change the opinion as to the efficiency of the knowledge management system which exists across the group as a whole.

\section{Conclusions and limitations of the paper}

The transfer of knowledge between companies in a network is a complex matter, certainly more difficult than in the case

Table 2: Key factors of effective knowledge management in networks: theory vs. practice

\begin{tabular}{|c|c|c|}
\hline No. & $\begin{array}{l}\text { Factors (criteria) fundamental to effective } \\
\text { knowledge management in a network }\end{array}$ & ArcelorMittal Group \\
\hline 1. & $\begin{array}{l}\text { Knowledge management as part of the company's busi- } \\
\text { ness strategy and mission, as well as business objec- } \\
\text { tives and processes }\end{array}$ & $\begin{array}{l}\text { Knowledge sharing and implementing best practices } \\
\text { is an integral part of ArcelorMittal's management phi- } \\
\text { losophy. }\end{array}$ \\
\hline 2. & Implementation of the "learning organization" concept & $\begin{array}{l}\text { Implemented in the group: constant learning, training } \\
\text { on different levels, Manager Academy. }\end{array}$ \\
\hline 3. & Ability to absorb knowledge & $\begin{array}{l}\text { Differentiated, depending on the particular capacities } \\
\text { of the member companies (the steel plants are located } \\
\text { in all continents; including companies from EU coun- } \\
\text { tries, such as Germany, France, Poland, as well as } \\
\text { non-EU members such as Kazakhstan, India, Ukraine, } \\
\text { Algeria, Trinidad and Tobago or USA). The infra- } \\
\text { structure of the companies situated in these countries } \\
\text { as well as the skills and competences of the employees } \\
\text { are varied. As the result, the ability to absorb knowl- } \\
\text { edge also differs. Generally one claims that the ability } \\
\text { to absorb knowledge is higher in the companies located } \\
\text { in the well developed economies such as Germany, } \\
\text { USA, France. }\end{array}$ \\
\hline
\end{tabular}


Table 2: Key factors of effective knowledge management in networks: theory vs. practice (continued)

\begin{tabular}{|c|c|c|}
\hline No. & $\begin{array}{l}\text { Factors (criteria) fundamental to effective } \\
\text { knowledge management in a network }\end{array}$ & ArcelorMittal Group \\
\hline 4. & Trust between network members & $\begin{array}{l}\text { The intra-organizational network at ArcelorMittal } \\
\text { promotes the existence of trust between its members. } \\
\text { The main reason is the type of relationships within the } \\
\text { ArcelorMittal network. The nature of the network, i.e. } \\
\text { intra-organizational one causes that there is no danger } \\
\text { of economic intelligence and information leakage as } \\
\text { the companies are the members of the same corpora- } \\
\text { tion. Opportunistic behaviour is also limited. }\end{array}$ \\
\hline 5 & $\begin{array}{l}\text { Character of the relationships within the network } \\
\text { (strong vs. weak) promoting the transfer of complex } \\
\text { knowledge }\end{array}$ & $\begin{array}{l}\text { Strong relationships between members of the intra- } \\
\text { organizational network of ArcelorMittal, facilitating } \\
\text { exchange of complex technical knowledge on steel } \\
\text { manufacturing processes (e.g. improvement of the } \\
\text { operational effectiveness of the blast furnace, conver- } \\
\text { tor, steel melting shop or continuous casting). }\end{array}$ \\
\hline 6. & $\begin{array}{l}\text { The central unit as the initiator of the knowledge trans- } \\
\text { fer }\end{array}$ & $\begin{array}{l}\text { The Group HQ is the initiator of the knowledge trans- } \\
\text { fer, however bottom-up initiatives are also highly } \\
\text { welcome; meetings between managers from particular } \\
\text { functional areas in different companies and/or subsid- } \\
\text { iaries. }\end{array}$ \\
\hline 7. & $\begin{array}{l}\text { Knowledge Management Programs and the clarity of } \\
\text { rules therein }\end{array}$ & $\begin{array}{l}\text { Existence of Knowledge Management Programs in } \\
\text { different parts of the value chain: procurement \& logis- } \\
\text { tics, production, sales, etc. }\end{array}$ \\
\hline 8. & $\begin{array}{l}\text { Existence of an effective communication system and } \\
\text { infrastructure }\end{array}$ & $\begin{array}{l}\text { Very effective communication system, as well as infor- } \\
\text { mation infrastructure in all facilities and subsidiaries. } \\
\text { Existence of SAP, i.e. an integrated software solution } \\
\text { of ERP type that incorporates the key business func- } \\
\text { tions of the whole corporation. }\end{array}$ \\
\hline 9. & $\begin{array}{l}\text { Existence of coopetition, i.e. simultaneous cooperation } \\
\text { and competition between network members }\end{array}$ & $\begin{array}{l}\text { To some extent and related mostly to the group's sub- } \\
\text { sidiaries; however, this positively affects the operation- } \\
\text { al activity of the group as some degree of competition } \\
\text { stimulates greater innovation. }\end{array}$ \\
\hline 10. & Frequency of contacts between network members & $\begin{array}{l}\text { Often meetings (and benchmarking meetings), telecon- } \\
\text { ferences and videoconferences between managers from } \\
\text { the steel plants located throughout the world. } \\
\text { Visits of the selected managers in the steel plants } \\
\text { belonging to the group to share knowledge and skills. }\end{array}$ \\
\hline 11. & $\begin{array}{l}\text { Creation of the task teams in order to perform certain } \\
\text { actions }\end{array}$ & $\begin{array}{l}\text { Widely implemented and utilised; every new acquisi- } \\
\text { tion is prepared and managed at the first stage by a } \\
\text { selected group of experienced managers from different } \\
\text { parts of the value chain: finance, sales, production, } \\
\text { accounting, logistics etc. The same relates to the solv- } \\
\text { ing problems which are encountered during operation } \\
\text { and/or tasks imposed. }\end{array}$ \\
\hline 12 . & Division of labour and tasks & $\begin{array}{l}\text { Widely applied; inter disciplinary teams consisting of } \\
\text { specialists from different divisions of the group. }\end{array}$ \\
\hline 13. & $\begin{array}{l}\text { Existence of internal procedures and rules associated } \\
\text { with knowledge management }\end{array}$ & $\begin{array}{l}\text { Not confirmed in } 100 \% \text {, however, based on the data } \\
\text { presented above, one should assume that such proce- } \\
\text { dures really exist within the group. }\end{array}$ \\
\hline
\end{tabular}


of individual companies. However, a properly designed transfer system is a prerequisite for effective knowledge transfer in an intra-organizational network, which can assist in the generation of competitive advantage. It has even been claimed that one of the strategic options open to the steel industry is to engage in strategic networking and knowledge sharing within R\&D in energy-improving technologies (Study, 2008). High priority is given to innovation and close cooperation with customers with regard to development.

ArcelorMittal Group has implemented the assumptions of knowledge management program within its corporation. Almost all the criteria of effective knowledge management in its intra-organizational network have been met by the group. Some exceptions, albeit merely to an extent, are mostly the result of historical circumstances, i.e. the process of growth through acquisitions, and the acquisition of companies at different stages of organizational development, as well as organizational culture. For example, there are the companies both from developed as well as developing countries in the group. Algeria, Kazakhstan, Ukraine and some other economies belong to the latter group. This can limit the ability to absorb knowledge; however not excluding it completely, of course.

The case study analysed the particular situation of the global corporation operating in the steel industry. Based on theoretical assumptions, it analysed in details the components of knowledge management applied by the corporation in question. Therefore this case study may be utilised to put the hypotheses and verify them on a larger group of companies from different sectors of the economy. The universal nature of the case presented, i.e. the possibility to apply the findings of the paper in by the companies operating in a variety of sectors is the most important implication for the practice. Thus it could be regarded as our contribution to the existing knowledge about learning and knowledge transfer in networks.

The main limitations of the paper are mostly related to the inherent approach therein. It constitutes a case study analysis based on a particular global corporation, which operates in a traditional sector of the economy. Moreover, the group has successfully implemented the assumptions of a knowledge management program, which cannot be said of every company. Therefore, it is not possible to argue definitively that this concept would succeed in other companies, e.g. in high-tech industries.

\section{Literature}

Abrahamson, E. \& Fombrum, C.J. (1994). Macro cultures: determinants and consequences. Academy of Management Review, 19(4), 728-755.

Ahuja, G. (2000). Collaboration networks, structural holes and innovation: a longitudinal study. Administrative Science Quarterly, 45(3), 425-455, http://dx.doi.org/10.2307/2667105
Argote, L., McEvily, B. \& Reagans, R. (2003). Managing knowledge in organizations: an integrative framework and review of emerging themes. Management Science, 49(4), 571-582. http://dx.doi.org/10.1287 mnsc.49.4.571.14424

Barney, J. (1991). Firm resources and sustained competitive advantage. Journal of Management, 17(1), 99-120, http://dx.doi. org/10.1177/014920639101700108

Blois, K.J. (1990). Transaction costs and networks. Strategic Management Journal, 11(6), 493-496, http://dx.doi. org/10.1002/smj.4250110607

Boston Consulting Group (2007). Beyond the boom - the outlook for global steel. Available at: http://www.bcg.pt/documents/ file14947.pdf (accessed 29 September 2013).

Buckman, K. (2006). Taking knowledge sharing to the next level. Available at: http://www.knowledge-nurture.com (accessed 28 March 2010).

Conradie, P. (2010). Knowledge management as a sustainable competitive advantage in the steel industry". Minidissertation submitted in partial fulfilment of the requirements for the degree Master in Business Administration at the Vanderbijlpark campus of the North-West University, available at: http://dspace.nwu.ac.za/handle/10394/4806

Eisenhardt, K.M. (1989). Building theories from case study research. The Academy of Management Review, 14(4), 532550, http://dx.doi.org/10.2307/258557

Eunni, R.V., Kasuganti, R.R. \& Kos, A.J. (2006). Knowledge management processes in international business alliances: a review of empirical research. 1990-2003, International Journal of Management, 23(1), 34-42.

Fenno, R. (1986). Observation, context, and sequence in the study of politics. American Political Science Review, 80(1), 3-15, http://dx.doi.org/10.2307/1957081

Gajdzik, B. (2008). Concentration on knowledge and change management at the metallurgical company. Metalurgija, 47(2), 142-144.

Gilsing, V.A. \& Lemmens, Ch. (2007). Strategic alliance networks and innovation: a deterministic and voluntaristic view combined. Technology Analysis \& Strategic Management, 19(2), 227-249, http://dx.doi.org/10.1080/09537320601168151

Goerzen, A. (2007). Alliance networks and firm performance: the impact of repeated partnerships. Strategic Management Journal, 28(5), 487-509, http://dx.doi.org/10.1002/smj.588

Granboualan J, Scotting B., De Smedt, S. \& Van Hoey, M. (2008). Integrating steel giants: an interview with the ArcelorMittal postmerger manager. The McKinsey Quarterly, 2, 94-105.

Grant, R. M. (1996. Toward a knowledge-based theory of the firm. Strategic Management Journal, 27, 109-122, http://dx.doi. org/10.2307/2486994

Hamel, G. (1991). Competition for competence and interpartner learning within international strategic alliances. Strategic Management Journal, 12, 83-103, http://dx.doi.org/10.1002/ smj.4250120908

Hansen, M.T. (1999). The research-transfer problem: the role of weak ties in sharing knowledge across organization subunits. Administrative Science Quarterly, 44, 82-111, http://dx.doi. org/10.2307/2667029

Hutzschenreuter, T. \& Horstkotte, J. (2010). Knowledge transfer to partners: a firm level perspective. Journal of Knowledge Management, 14(3), 428-448, http://dx.doi.org/10.1108/136 73271011050148 
Ingram, P. \& Simons, T. (2002). The transfer of experience in groups of organizations: implications for performance and competition. Management Science, 48(12), 1517-1533, http:// dx.doi.org/10.1287/mnsc.48.12.1517.437

Johannessen, J. \& Olsen, B. (2003). Knowledge management and sustainable competitive advantage: the impact of dynamic contextual training. International Journal of Information Management, 23, 277-289, http://dx.doi.org/10.1016/S02684012(03)00050-1

Klonoski, R. (2013). The case for case studies: deriving theory from evidence. Journal of Business Case Studies, 9(3), 261266.

Kok, J.A. (2004). Framework for managing knowledge in an enterprise to gain competitive advantage. South African Journal of Information Management, 6(4), 1-9, http://dx.doi. org/10.4102/sajim.v6i4.351

Kotabe, M., Martin, X. \& Domoto, H. (2003). Gaining from vertical partnerships: knowledge transfer, relationship duration and supplier performance improvement in the U.S. and Japanese automotive industries. Strategic Management Journal, 24(3), 293-316, http://dx.doi.org/10.1002/smj.297

Kuiken, J. \& Van der Sijde, P. (2010). Knowledge transfer and disseminative capacity: a review and propositions for further research on academic knowledge transfer. Available from http://proceedings.utwente.nl/53/1/Kuiken.pdf

Lake, P. \& Erwee, R. (2005). Knowledge exchange in a regional network, International Journal of Organisational Behaviour, 9(6), 642-658.

Lee, C.Y., \& Wu, F.C. (2010). Factors affecting knowledge transfer and absorptive capacity in multinational corporations, The Journal of International Management Studies, 5(2), 119-126.

Lisiński, M., Sroka, W., Brzeziński, P., Jabłoński, A., \& Stuglik, J. (2012). Application of modern management concepts by Polish companies - analysis of research results. Organizacija, 45(2), 41-49, http://dx.doi.org/10.2478/v10051-012-0005-5

Lorenzoni, G. \& Lipparini, A. (1999). The leveraging of interfirm relationships as a distinctive organizational capability: a longitudinal study. Strategic Management Journal, 20(4), 317-338, http://dx.doi.org/10.1002/(SICI)10970266(199904)20:4<317::AID-SMJ28>3.0.CO;2-3

Marelli, A.F. (2007). Collecting data through case studies. Performance Improvement, 47(7), 39-44, http://dx.doi. org/10.1002/pfi.148

Minbaeva, D.B. \& Michailova, S. (2004). Knowledge transfer and expatriation in multinational corporations. The role of disseminative capacity. Employee Relations, 25(6), 663-679, http://dx.doi.org/10.1108/01425450410562236

Mitchell, J.C. (1983). Case and situation analysis. The Sociological Review, 31(2), 187-211, http://dx.doi.org/10.1111/j.1467954X.1983.tb00387.x

Nonaka, I. (1991). The knowledge-creating company. Harvard Business Review, 11, 96-104.

Parent, R., Roy, M. \& Jacques, S. (2007). A systems-based dynamic knowledge transfer capacity model. Journal of Knowledge Management, 11(6), 81-93, http://dx.doi. org/10.1108/13673270710832181

Patton, M.Q. (2002). Qualitative research and evaluation methods (3 ${ }^{\text {rd }}$ ed.). Thousand Oaks. CA: Sage.

Piekkari, R., Welch, C. \& Paavilainen, E. (2009). The case study as disciplinary convention: Evidence from international business journals. Organizational Research Methods, 12(3), 567-589, http://dx.doi.org/10.1177/1094428108319905

Powell, W.W. (1998). Learning from collaboration: knowledge and networks in the biotechnology and pharmaceutical industries. California Management Review, 40(3), 228-240, http://dx.doi. org/10.2307/41165952

Polanyi, M. (1966). The tacit dimension, Garden City: Doubleday \& Co.

Reagans, R. \& McEvily, B. (2003). Network structure and knowledge transfer: the effects of cohesion and range. Administrative Science Quarterly, 48, 240-267, http://dx.doi. org/10.2307/3556658

Richter, F.J. \& Vettel, K. (1995). Successful joint ventures in Japan: transferring knowledge through organizational learning. Long Range Planning, 28(3), 37-45, http://dx.doi. org/10.1016/0024-6301(95)00019-F

Smith, N.C. (1990). The case study: a useful research method for information management. Journal of Information Technology, 5, 123-13, http://dx.doi.org/10.1057/jit.1990.30

Spender, J.C. \& Grant, R.M. (1996). Knowledge and the firm: overview. Strategic Management Journal, 17, 5-9, http:// dx.doi.org/10.2307/2486987

Sroka, W. (2010a). Alliance networks: the case of multinational corporations. Organizacija 43(4), 165-172, http://dx.doi. org/10.2478/v10051-010-0016-z

Sroka, W. (2012). Cooperative strategies and their benefits - theory vs. research results. Management: Science and Education, 1(1), 44-48.

Sroka, W. (2010b). Mergers and acquisitions or inter-organizational cooperation? Determinants of choice, 29th International Conference on Organizational Science Development "People and Organization", Portoroz, Slovenia, 24-26 March, pp. 1434-1441.

Study on the competitiveness of the European Steel Sector within the framework contract of sectorial competitiveness studies - ENTR/06/054, Final report, August 2008, Available at: http://ec.europa.eu/enterprise/sectors/metals-minerals/files/ final_report_steel_en.pdf

Szulanski, G. (1996). Exploring internal stickiness: impediments to the transfer of best practice within the firm. Strategic Management Journal, 17, 27-43, http://dx.doi. org/10.2307/2486989

Tang, F. (2011). Knowledge transfer in intra-organization networks. Systems Research and Behavioural Science, 28(3), 270-282, http://dx.doi.org/10.1002/sres.1074

Thomas, G. (2011). A typology for the case study in social science following a review of definition, discourse and structure. Qualitative Inquiry, 17(6), 511-521, http://dx.doi. org/10.1177/1077800411409884

Tsai, W. (2001). Knowledge transfer in intraorganizational networks: effects of network position and absorptive capacity on business unit innovation and performance. Academy of Management Journal, 44(5), 996-1004, http://dx.doi. org/10.2307/3069443

Tsang, E.W.K. (2013). Case study methodology: causal explanation, contextualization, and theorizing. Journal of International Management, 19(2), 195-202, http://dx.doi.org/10.1016/j.intman.2012.08.004

Uzzi, B. (1997). Social structure and competition in interfirm networks: the paradox of embeddedness, Administrative Science Quarterly, 42(1), 35-67, http://dx.doi.org/10.2307/2393808 
Welch, C., Piekkari, R., Plakoyiannaki, E. \& PaavilainenMäntymäki, E. (2011). Theorising from case studies: towards a pluralist future for international business research. Journal of International Business Studies, 42(5), 740-762, http:// dx.doi.org/10.1057/jibs.2010.55

Wiechoczek, J. (2009). Foreign direct investment of Asian companies in Central and Eastern Europe as an element of expansion strategy on the European Union market. Journal of Economics \& Management, 6, 188-215.

Wynn, J., \& Williams, C.K. (2012). Principles for conducting critical realist case study research in information systems. MIS Quarterly, 36(3), 787-810.

Yin, R.K. (1994). Case study research design and methods, $2^{\text {nd }}$ ed. Applied Social Research Methods Series, Volume 5, Thousand Oaks CA: Sage Publications.

Yin, R.K. (1981). The case study crisis: some answers. Administrative Science Quarterly, 26, 58-65, http://dx.doi. org/10.2307/2392599

Zahra, S. \& George G. (2002). Absorptive capacity: a review, reconceptualization and extension. Academy of Management Review, 27(2), 185-203, http://dx.doi.org/10.2307/4134351

Włodzimierz Sroka specializes in theoretical and practical issues relating to the management and strategic management. $\mathrm{He}$ is the author of several scientific articles about strategic alliances, mergers and acquisitions, strategy, restructuring and alliance networks published both in Polish and international journals. His research activities mainly include cooperative strategies, and mergers and acquisitions. He holds his Ph.D., M.Sc. and B.Sc. degrees in Management and Marketing from the Karol Adamiecki University of Economics in Katowice, as well as D.Sc degree (habilitation) from the University of Zilina (Slovakia). Currently he is an Associate Professor and Vice Rector for
Science at the Academy of Business in Dabrowa Górnicza (Poland). He was previously employed in different managerial positions in both the steel and machine industries.

Joanna Cygler: M.A (Economics), Ph.D. (Management) and Habilitation (Strategic Management) from the Warsaw School of Economics (SGH). Associate Professor (Institute of Management, Faculty of Management and Finance) at Warsaw School of Economics. Specialist of international business cooperation. Authoress of numerous scientific publications on strategic alliances, business coopetition and network relations published in various countries. Worked for the Chancellery of the President of Poland (special advisor), responsible for international economic initiatives of the President and cooperation with international organizations (e.g. OECD, WEF, UN). She also worked for the Agency for Foreign Investment in Poland, (Director, Research Department, responsible for international investment cooperation, coordinated the biggest foreign investment projects in Poland) and the Ministry of Economy (research projects). Coordinated many research projects financed by Polish and American (Fulbright research scholarship, University of Minnesota) scientific organizations.

Bożena Gajdzik specializes in theoretical and practical issues relating to the restructuring processes in manufacturing enterprises after transformation of economic system in Central European Countries. She is the author of several scientific articles and books. She specializes in restructuring of metallurgical enterprises in Poland and in other countries. She holds her Ph.D. degree in Economics from the Karol Adamiecki University of Economics in Katowice. Currently she is a lecturer (Assistant Professor) at the Silesian University of Technology in Gliwice (Poland). 